\title{
Onko sivistyksen pelto valmiiksi kynnetty?
}

Jorma Kaimio

\author{
“Jos jotain sivistykseltä etsisin määrittelemättä \\ itse, mitä sivistyksellä ymmärrän, se on ennen kaikkea \\ voimakasta yksilöllistä kokemista. Sellaista \\ kulttuurikokemusta, joka vaikuttaa ihmiseen ja sitä \\ kautta, hänen persoonallisuutensa kehittymisen kautta, \\ muuttaa edes pieneltä osalta maailmaa, \\ jossa me elämme."
}

$\mathrm{M}^{\mathrm{u}}$ uuten tuntemattomaksi jäänyt kreikkalainen runoilija Khoirilos Samoslainen huokaisi 300-luvulla e.Kr. vapaasti siteeraten: "Ah, miks' en ollut kirjailija ennen Homerosta, ennen suuria kreikkalaisia draamakirjailijoita, aikana, jolloin pelto oli kyntämätön ja siemen istuttamatta. Nyt, 300 vuotta myöhemmin, kaikki on jo kirjoitettu, kaikki on jo sanottu. Miten minä nyt voin nousta suureen mestaruuteen?“

Tämä kirjailijan huokaisu tuli mieleeni ajatellessani kaikkia meitä, jotka joudumme jo kynnetylle pellolle omia ajatuksiamme esittämään. En kuitenkaan aio tyhjentää puheenvuorossani koko sivistyksen siemenvakkaa.

$\mathrm{O}$ len hiljan jonkun verran perehtynyt viime vuosisadan jälkipuoliskon kulttuurin vaikuttajiin, ei niinkään itse kulttuurin tekijöihin, vaan niihin, jotka olivat rakentamassa tämän maan kulttuurikuvaa. Merkittävänä joukkona siinä työssä olivat ne henkilöt, jotka olivat Kansanvalistusseuraa 125 vuotta sitten perustamassa.
Voidaan tavallaan sanoa, että heillä oli pelto hyvin pitkälle kyntämätön. Kaikki se työ, mitä he pystyivät tekemään, kantoi satoa. Suomalaisen kulttuurin kaanon oli vasta muotoutumassa. Heillä oli mahdollisuudet voimakkaasti vaikuttaa tähän. Arvattavasti heidän takanaan oli tavaton määrä idealismia. Esimerkiksi sopii oman yhtiöni WSOY:n perustaja Werner Söderström, joka 19-vuotiaana suomea osaamattomana porvoolaisen kirjanpainajan poikana ryhtyi perustamaan tavattoman korkealla ambitiotasolla toimivaa suomenkielistä kustantamoa. Hän ei pystynyt käymään kirjeenvaihtoa Pietari Päivärinnan kanssa, koska Pietari Päivärinta kieltäytyi ruotsinkielisten kirjeiden vastaanottamisesta. En osaa sanoa, olisiko hän ymmärtänyt ruotsia, mutta Werner Söderström turvautui apuun kirjeenvaihdossa hänen kanssaan.

Silti nimenomaan suomalaisen kirjallisuuden kustantaminen oli se ideologinen päämäärä, johon tämä kansanvalistaja pyrki. Merkittävää mielestäni näissä varhaisissa kulttuurimme rakentajissa oli se, että toisaalta he halusivat pystyttää 


\section{N ̈̈ K Ö KUL M I A}

merkkipaalut meidän kulttuurillemme, lähes ylittämättömät esikuvat, joiden paaluja katsellen tulevat kulttuuripyrinnöt nousisivat yhä korkeammalle.

$\mathrm{T}_{\mathrm{k}}$ oisaalta he arvostivat tavattoman paljon sitä kulttuuria, joka kansan parissa oli jo olemassa ja sitä työtä, joka kansan sivistystason nostamiseksi tuli tehtyä.

Werner Söderströmille Kauppis-Heikki oli yhtä tärkeä kuin Juhani Aho tai Järnefeltin koulun muut kasvatit, ja tämän kulttuurin levittäminen mahdollisimman laajalle vähäväkisen kansan tietoon oli keskeinen päämäärä tuossa työssä.

Tämän päivän kansanvalistajat tai kansansivistäjät joutuvat ehkä huokaisemaan: "Mutta nythän kaikki osaavat lukea“. Nythän kaikki käyvät vähintään peruskoulun. Samanaikaisesti me saamme lehdistä lukea yhä uusia nuorison parissa tehtyjä gallupeja, jotka kertovat, että Stalin on suomalaiselle nuorisolle aika tuntematon henkilö, että meidän poliittinen järjestelmämme on hyvinkin epäselvä lukiota käyvälle nuorisolle, tai että männyn ja kuusen erottaminen toisistaan on osalle nuorisoamme vaikea tehtävä.

E hkä voisimme todeta, että uuden kansanvaistuksen aika on koittanut. Se, mitä me pidämme itsestään selvänä, on kaikkea muuta kuin itsestään selvää. Meidän sivistystasomme on ehkä rapistumassa huolestuttavammin, kuin mitä voimme kuvitella.

Todetessani tämän joudun heti kysymään: "Mikä sivistystaso? Mikä sivistys?" Määrittelemmekö me moittiessamme nuorisoamme tuon sivistyksen omista arvoistamme, omasta hieman museaalisesta näkökulmastamme katsoen? Osaammeko itse vastata kysymykseen: "Mikä on bitti? Mikä on bosoni? Tai ketkä laulavat Apulanta-yhtyeessä?“

Voimme vielä huudahtaa, että eihän Apulanta ole kulttuuria, ei se ole sivistystä. Mutta voi väittää, että alkeishiukkasten nimien tuntemattomuus olisi jotenkin sivistyneelle ihmiselle perusteltua. Eikö siinä olla kuitenkin aika keskeisen maailmankaikkeuden kysymyksen äärellä?

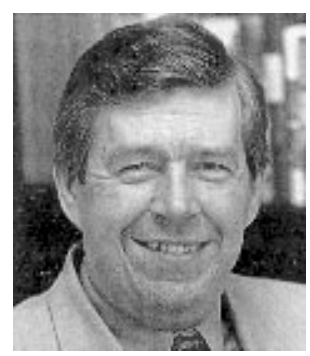

Jorma Kaimio

$\mathrm{V}_{\mathrm{t}}$ oimme taas mennä runsaat sata vuotta ajassa taaksepäin ja todeta, että kyllähän darwinismin vaikutus myös suomalaisen kirjallisuuden kehittymiseen on ollut tavattoman voimakas. Kvanttifysiikka vaikuttaa ties mihin asioihin nykyään. Jos emme erota sen vaikutusta kirjallisuuteemme, voisiko syynä olla, ettei sivistyneistö katso luonnontieteellisiin uusimpiin tutkimustuloksiin perehtymisen olevan kovin olennainen osa tätä meidän kirjallista sivistystämme. Nostakaamme peili kasvojemme eteen samalla, kun päivittelemme sitä, että kaikki meille tärkeät asiat eivät ole seuraavalle sukupolvelle enää niin itsestään selviä.

Tiemme käy epäilemättä uuteen kansanvalistukseen. Ehkä meidän pitää ottaa siinä oppia noista 125 vuoden takaisista aatteista, jolloin toisaalta katsottiin kulttuurin merkkipaalut välttämättömiksi ja toisaalta katsottiin, että kansan omassa parissa elävä kulttuuri on vähintään yhtä arvokasta kuin korkeakulttuurin merkkiteokset.

$\mathrm{V}_{\mathrm{k}}$ iime aikoina on käyty keskustelua uudesta kulttuurikaanonista. Tavallaan tuollaisen kaanonin kautta käsite "sivistys" on ehkä helpoimmin määriteltävissä. Mutta joudun kyllä itse hyvinkin ongelmalliseen tilanteeseen pohtiessani, pitäisikö määritellä tietyt kirjailijat, joilta jokainen suomalainen koululainen olisi lukenut ainakin yhden teoksen ylioppilaaksi kirjoittaessaan. Pitäisikö muuallakin suosia tällaisten arvokkaimpien teosten listoja, järjestää nettiäänestyksiä tai nimetä raateja, jotka valitsevat ne sivistyksen kulmakivet, jotka jokaisen suomalaisen tulee tuntea? 
iitä huolimatta, että itse epäilemättä olen amOnattini vuoksi kulttuurivaikuttaja, joka väistämättä vaikuttaa siihen, mitä suomalaiset lukevat, mitä he ehkä lukemisensa kautta tietävät, minua on alkanut yhä enemmän emmityttää kysymys siitä, millä oikeudella joku kulttuurivaikuttaja tai kulttuuripoliitikko kertoo, mikä on hyvää, mikä on huonoa, mikä kuuluu kaiken kansan luettavaksi.

Toisaalta katson, että esikuvien puuttuminen on ainakin jossain määrin monen yhteiskunnallisen ongelmamme syynä. Tässä suhteessa vuosituhannen vaihde meidän demokraattisessa, luterilaisessa yhteiskunnassamme on aika poikkeuksellinen maailmanhistoriallinen aika. Antiikin ihmisillä oli sankarinsa, jotka kelpasivat niin hyvässä kuin pahassakin esikuvaksi. Katolisella maailmalla on omat pyhimyksensä, monarkioissa on kuninkaallisensa, diktatuureissa hallitsijat, joiden esikuvallisuus voi olla kyseenalaistettavaa, mutta joita ei saa kuitenkaan kyseenalaistaa.

$\mathrm{M}$ eillä on esikuvaksi pyrkiviä julkisuuden tähdenlentoja, jotka tulevat ja menevät ja joiden esikuvallisuus ei ole ainakaan pysyvää luonteeltaan, jos ylipäätänsä hahmotettavaa. Olen oikeasti sitä mieltä, että ihminen, olkoon kuinka sivistynyt tahansa, kaipaa kuitenkin esikuvia maailmaansa rakentamaan. Ehkä kulttuurin alueelta, kirjallisuudesta, näitä esikuvia olisi helpoiten löydettävissä. Onhan kirjallisuus tunnetusti ihmisyyden persoonallisuuden rakentamisessa, waltarimaista ajatusta seuraten, keskeinen tekijä. Jokainen luettu kirja, jos sen on oikein lukenut, muuttaa vähän meidän persoonallisuuttamme.

Sivistyksellä ei ole välinearvoa sinänsä, mutta se, mikä sivistyksestä seuraa, on arvokasta.

Samanaikaisesti, kun kaipaan näitä kaanoneita, näitä esikuvia, vielä voimakkaammin korostaisin sitä, että lukeminen, kulttuurin taiteen kokeminen, on ja sen täytyy olla persoonallinen tapahtuma. Täytyy lähteä siitä, että jokainen lukija kokee teoksen eri tavalla. Tästä näkökulmasta en hyväksy sitä, että joku tulee kertomaan minulle, mikä on hyvä tai arvokas kirja, mikä taas on huono tai vähäpätöinen kirja. Ei sitä voi ratkaista kukaan muu kuin minä itse. Jos ajattelemme kulttuurin etenemistä, tälläkin saralla erilaisuus, dialogi, on tärkeämpää kuin konsensus, samojen asioiden käsittely.

$\mathrm{O}$ len usein itse pohtinut kysymystä: Miksi niin monen kulttuurin alussa on suurin nimi? Miksi koko antiikin kirjallisuus ei löydä Homeroksen voittanutta? Miksi meidän romaanitaiteemme on vaikea löytää Aleksis Kiven Seitsemän veljeksen voittanutta? Miksi Kalevalan suuruus on edelleen niin yli päitten nousevaa? Pois minusta se ajatus, että suuri pioneeri varjostaa tai määrittelee sitä työtä, joka jatkossa tulee. Mutta kaanon olkoon alku, ei loppu.

os siis jotain sivistykseltä etsisin määrittelemättä
itse, mitä minä sivistyksellä ymmärän, se on ennen kaikkea voimakasta yksilöllistä kokemista. Sellaista kulttuurikokemusta, joka vaikuttaa ihmiseen ja sitä kautta, hänen persoonallisuutensa kehittymisen kautta, muuttaa edes pieneltä osalta maailmaa, jossa me elämme.

Sama kysymys, jota kustantaja joutuu käsikirjoituksia arvioidessaan pohtimaan, tuo määrittely, jonka minä olen pukenut suurin piirtein sanoihin: Avaako tämä käsikirjoitus jonkun pienenkin ikkunan siihen todellisuuteen jossa me elämme, ikkunan, joka tähän asti on ollut kiinni? Jos se avaa, se muuttaa meitä, jos se muuttaa meitä, se muuttaa maailmaa, vaikka muut eivät ehkä sitä huomaisikaan.

Minulle sivistys on intensiteettiä. Se on historiallisesti syvää, tässä ajassa olevaa. Siitä puuttuu museaalisuus, jos museaalisuus nähdään liikkumattomaksi, liikuttamattomaksi. Rakastan voimakkaita museoita.

Puheenvuoro kuului osana Kansanvalistusseuran Mitä on sivistys? -seminaariin 3.2.1999. 